\title{
Dendrometric evaluation of a clonal population of Tectona grandis in forest-livestock system
}

\author{
Luciano de Souza Maria ${ }^{1 *}$ Felipe Adolfo Litter $^{1}$ Márcia de Almeida Carneiro ${ }^{1}$ \\ Fabrícia Rodrigues da Silva ${ }^{1}$ Marcos Leandro Garcia ${ }^{1}$ Marco Antonio Camillo de Carvalho ${ }^{1}$
}

${ }^{1}$ Departamento de Agronomia, Faculdade de Ciências Agrárias e Biológicas, Universidade do Estado de Mato Grosso (UNEMAT), Campus de Alta Floresta, 78580-000, Alta Floresta, MT, Brasil. E-mail: tiolucio123@gmail.com. *Corresponding author.

ABSTRACT: Production of Tectona grandis (teak) in integrated systems with livestock or agriculture demonstrates high potential of financial return. However, studies on the development of teak are still scarce, especially in the northern region state of Mato Grosso. In this study we sought to evaluate dendometric variables of a clonal population of teak in a forest-livestock integration system (LFIS), during a period of 53 months in the city of Alta Floresta, Mato Grosso, Brazil. For this purpose, three installments were samples, a total of 360 individuals, and for each the diameter was measured at 1.3 meters from the base so as to calculate the total volume, the current annual increment (CAI) and mean annual increment (MAI), and five adjusted regression models. The Hoerl model provided the highest adjusted coefficient of determination $\left(R^{2} a j\right)$, lowest standard error of estimate (Syx), coefficient of variation (CV\%), and from this the growth curves were developed. Clonal stands of teakin the forest-livestock system presented increases in DBH, height and volume were superior in relation to other scientific studies with teak, indicating their viability in integrated systems with pastures in the region.

Key words: Growth, model, LFIS, teak.

Levantamento dendrométrico de um povoamento clonal

de Tectona grandis, em sistema silvipastoril

RESUMO: A produção de madeira de Tectona grandis (teca) em sistemas integrados com pecuária ou agricultura demonstra alta perspectiva de retorno financeiro. Entretanto, estudos sobre o desenvolvimento da teca ainda são escassos, principalmente na região norte de Mato Grosso. O objetivo do trabalho foi avaliar o crescimento das variáveis dendrométricos de um povoamento clonal de teca, em um sistema silvipastoril (iPF), ao longo de 53 meses, no municipio de Alta Floresta-MT, Brasil. Para isso, foram amostradas três parcelas, totalizando 360 indivíduos, sendo que em cada indivíduo foi mensurado o diâmetro a 1,3 $\mathrm{m}$ do solo e altura total. Em seguida realizou-se o cálculo do volume. Para descrever o crescimento da variável diâmetro, altura total e volume foi realizado o ajuste através de cinco modelos matemáticos que expressam o crescimento ao longo do tempo. Posteriormente, foram calculados o incremento corrente anual (ICA) e incremento médio anual (IMA). O modelo de Hoerl apresentou melhores resultados de $R^{2} a j$, obteve menores valores para o erro padrão de estimativa (Syx) e para o CV\%, com isso, foi selecionado para a elaboração das curvas de crescimento. O povoamento clonal de teca no iPF apresentou incremento em DAP, Altura e volume foram superiores em relação a outros estudos cientificos com teca, indicando sua viabilidade em sistemas integrados com pastagens na região.

Palavras-chave: modelos de crescimento, Sistema iPF, teca.

\section{INTRODUCTION}

In Mato Grosso cattle ranching has expanded greatly in recent decades (SILVA et al. 2016). However, it is noted that 100 million hectares of Brazilian pastures showed some degree of degradation (NIERI et al., 2018).

The forest-livestock integration system (LFIS) stands out among the various types of systems, with inclusion of tree components providing animal comfort and improving soil fertility, resulting in greater productivity and profitability for rural producers due to the production timber products and animal protein in the same area (PAULA et al., 2013). Study of the silvicultural behavior of the species inserted in the LFIS is relevant, especially forest species with potentially high-value timber (NIERI et al., 2017). The Tectona grandis L. F. (teak) species from the tropical monsoon forests of Southeast Asia (MORETTI et al., 2014) shows potential for reforestation and the production of wood for sawmills (SILVA et al., 2016). 
In the state of Mato Grosso, it was estimated that more than 67.329 hectares were planted, an increase of $14.67 \%$ between the years of 2009 and 2012 (MORETTI et al., 2014), and usually implanted in mosaics, mixed with native forest, agriculture and pasture (FAMATO, 2013).

The growth of teak species varies according to local soil and climatic conditions, mainly as a function of precipitation, relative humidity and temperature (SINHA et al., 2011). There is; therefore, a need for scientific studies in the state of Mato Grosso for silvicultural development of teak and its integration with agricultural crops, growth monitoring and production (MEDEIROS et al., 2015).

Schuhli and Paludzyszyn Filho (2010) affirmed that there is a special interest in Brazil on studies of the potential for recovery of degraded areas, productivity in silvicultural, livestock and/or agriculture integration systems, the participation of legal reserve areas on the production process and the feasibility of teak production for small producers.

Cultivation of teak in the extreme north of Mato Grosso can be considered an alternative of stimulating potential for homogeneous forest cultivations and in consortium with pastures, characterized as an advantage for differentiated use of the soil in the forest-livestock integrated production system. The objective of the present study was to evaluate the development of the diameter at breast height (DBH), height and volume of a clonal stand of teak in LFIS, for 53 months, via different mathematical models and evaluated the mean annual increase (MAI) and current annual increase $(\mathrm{CAI})$ of clonal seedlings in plantations integrated with pastures.

\section{MATERIALS AND METHODS}

The studied site is located in an area belonging to the company Forest Bacaeri, with geographical coordinates of $56^{\circ} 52^{\prime} 44^{\prime \prime} \mathrm{W}$ and $09^{\circ} 58^{\prime} 17^{\prime} \mathrm{S}$, and elevation of $230 \mathrm{~m}$. The climate according to the Köppen classification is Aw, tropical rainy season with high rainfall (2.200 to $2.550 \mathrm{~mm}$ ), characterized by a rainy tropical climate in which the mean annual temperature varies from 23 to $25^{\circ} \mathrm{C}$ and with well-defined seasons: summer rains and winter droughts (ALVARES et al., 2013).

The soil of the experimental area is classified according to Embrapa (2013) as red-yellow latosol dystrophic (Oxisol) with a sandy clay texture, presenting the following chemical characterization at the depth of $0-0.20 \mathrm{~m}$ (Table 1 ).
Table 1 - Chemical and physical properties of the experimental soil.

\begin{tabular}{lc}
\hline Characteristic & Value \\
\hline $\mathrm{pH}\left(\mathrm{CaCl}_{2}\right)$ & 4.8 \\
$\mathrm{OM}^{*}\left(\mathrm{~g} \mathrm{dm}^{-3}\right)$ & 24.0 \\
$\mathrm{P}-\mathrm{Mehlich}^{-1}\left(\mathrm{mg} \mathrm{dm}^{-3}\right)$ & 1.9 \\
$\mathrm{~K}-\left(\mathrm{mmol}_{(\mathrm{c})} \mathrm{dm}^{-3}\right)$ & 1.8 \\
$\mathrm{H}^{+}+\mathrm{Al}^{3+}\left(\mathrm{mmol}_{(\mathrm{c})} \mathrm{dm}^{-3}\right)$ & 40.5 \\
$\mathrm{Ca}^{+2}\left(\mathrm{mmol}_{(\mathrm{c})} \mathrm{dm}^{-3}\right)$ & 20.8 \\
$\mathrm{Mg}^{+2}\left(\mathrm{mmol}_{(\mathrm{c})} \mathrm{dm}^{-3}\right)$ & 5.1 \\
$\mathrm{Al}^{-3}\left(\mathrm{mmol}_{(\mathrm{c})} \mathrm{dm}^{-3}\right)$ & 1.8 \\
$\mathrm{CEC}^{* *}\left(\mathrm{mmol}_{(\mathrm{c})} \mathrm{dm}^{-3}\right)$ & 67.9 \\
$\mathrm{SB}^{* * *}(\%)$ & 43.5 \\
\hline $\mathrm{Sand}$ fraction $\left(\mathrm{g} \mathrm{kg}^{-1}\right)$ & 554 \\
\hline Silt fraction $\left(\mathrm{g} \mathrm{kg}^{-1}\right)$ & 86 \\
\hline Clay fraction $\left(\mathrm{g} \mathrm{kg}^{-1}\right)$ & 360 \\
\hline
\end{tabular}

Where: ${ }^{*} \mathrm{OM}=$ organic matter ${ }^{* *} \mathrm{CEC}=$ Cation Exchange Capacity ${ }^{* * *} \mathrm{SB}=$ Base of saturation.

The experimental design was a randomized block design (RBD)in the planting lines of clonal seedlings of Tectona grandis L. F. in a forestlivestock system, tested five growth models, with four replications. The area of study corresponds to 2.7 ha, inserted in an area of 45 ha, composed of pasture (Urochloa brizantha cv. Marandu) and teak, in LFIS and spacing of $25 \times 3 \mathrm{~m}$. Clonal seedlings (Clone A1) were obtained from the clonal garden. After the plants completed one year of growth, three plots with 120 individuals each were selected in the growing area, totaling 360 trees.

Evaluations began in November 2009 and were conducted through May 2013, totaling seven measurements. For each individual, the circumference at breast height $(\mathrm{CBH})$ was measured at 1.30 meters from the ground using a tape measure, for subsequent conversion to diameter at breast height (DBH). For the measurements of height metallic rulers of $12 \mathrm{~m}$, graduated in meters, were used. Because the population was young, the rigorous cubage was not determined to establish the form factor. Thus, the artificial form factor was adopted as reported by DRESCHER et al. (2014) for teak (Table 2).

With the data on diameter $(\mathrm{cm})$, height $(\mathrm{m})$ and volume $\left(\mathrm{m}^{3}\right)$ as a function of age, growth models were adjusted for each of the dendrometric variables, whose models are presented in table 3 .

Five mathematical models were adjusted by linear regression (Minimum Squares Method). 
Table 2 - Factor of artificial form according to the age of the settlement of the Forest Bacaeri. (DRESCHER et al., 2014).

\begin{tabular}{lc}
\hline Age (months) & Form actor \\
\hline 12 & 0.621 \\
17 & 0.610 \\
23 & 0.599 \\
31 & 0.557 \\
37 & 0.532 \\
46 & 0.496 \\
53 & 0.488 \\
\hline
\end{tabular}

Models were adjusted for spacing, utilizing the $\mathrm{R}$ software (R Core Team, 2015), and the variables were selected via a stepwise function. Selection of the best model initially confirmed the lowest relative standard error of the estimate (Syx \%), the largest adjusted coefficient of determination $\left(\mathrm{R}^{2} \mathrm{Aj}\right)$, the graphic distribution of the bias-free residuals $(\mathrm{E} \%)$ and the normality of the residuals, by using the Shapiro-Wilk test at $\mathrm{p}<0.05$ significance.

\section{RESULTS AND DISCUSSIONS}

The diameter estimates as a function of age demonstrated that the equations present statistical parameter values for the adjusted coefficient of determination $\left(R^{2} A j\right.$.) higher than 0.90. Standard error values of the estimates (Syx) were less than $15.5 \%$ (Table 4 ). The equations adjusted well to the observed data, positive describing the growth in diameter of the teak stand.

The equation $\operatorname{Ln}(\mathrm{DBH})=2.590-19.775$ $\mathrm{x}(1 / \mathrm{t})+0.120($ Lnt $)$, adjusted by the Hoerl model
Table 3 - Models adjusted for diameter, total height and volume growth as a function of age of the Forest Bacaeri.

\begin{tabular}{llc}
\hline Equation & Mathematical Model & Author \\
\hline 1 & $\ln (y)=\beta_{0}+\beta_{1} * \ln t+\beta_{2} * \ln ^{2} t$ & Backman \\
2 & $\ln (y)=\beta_{0}+\beta_{1} *(1 \mid t)$ & Schumacker \\
3 & $\ln (\mathrm{y})=\beta_{0}+\beta_{1} *(1 \mid \mathrm{t})+\beta_{2} * \ln \mathrm{t}$ & Hoerl \\
4 & $\ln (\mathrm{y})=\beta_{0}+\beta_{1} * \ln \mathrm{t}+\beta_{2} * \mathrm{t}$ & Gram \\
5 & $\ln (\mathrm{y})=\beta_{0}+\beta_{1} * \mathrm{t}+\beta_{2} * \mathrm{t}^{2}+\beta_{3} * \mathrm{t}^{3}$ & Moissev
\end{tabular}

Where: $\mathrm{Ln}=$ natural or neperian logarithm, $(\beta 0, \beta 1, \beta 2, \beta 3)=$ coefficients to be estimated, $\mathrm{t}=$ age (months), y $(\mathrm{DBH}$, height, volume).

showed better precision and progressive increase in DBH (Figure 1B), presented the lowest standard error $(14.49 \%)$ and demonstrated a higher value for the adjusted coefficient of determination (0.914), and the graphical distribution of the residues showed that the regression coefficients were significant and there was no bias (Figure 1A).

Behavior of residual distribution of heights (H) presented the same trend as $\mathrm{DBH}$, where the Hoerl model showed a better residual distribution and a better adjustment to growth in height as a function of age (Figure 1C). The Hoerl model for description of the height growth curve demonstrated the accelerated growth of teak in the early years of development (Figure 1D).

Analyzing table 5 and figure $1 \mathrm{C}$ it can be observed that the Hoerl equation more adequately represented height growth, since it presents a smaller standard error $(12.64 \%)$, higher value of $\mathrm{R}^{2} \mathrm{Aj}=$ 0.9084 and homogeneous distribution of residues.

Estimates of the total volume as a function of age showed similarities with the estimates of

Table 4 - Statistical parameters of the equations tested to adjust the growth in diameter as a function of age of the Forest Bacaeri.

\begin{tabular}{|c|c|c|c|c|c|c|c|c|}
\hline \multirow[t]{2}{*}{ Equation } & ------- & -----Coef & ts--------- & -------. & & & & \\
\hline & $\beta_{0}$ & $\beta_{1}$ & $\beta_{2}$ & $\beta_{3}$ & $\mathrm{R}^{2} \mathrm{Aj}$ & Syx & $\mathrm{CV} \%$ & $\mathrm{~F}$ \\
\hline Schumacker & 3.10 & -22.52 & - & - & 0.913 & 0.145 & 1.45 & $12951^{*}$ \\
\hline Backman & -4.88 & 3.41 & -0.38 & & 0.910 & 0.148 & 1.47 & $6177^{*}$ \\
\hline Hoerl & 2.59 & -19.77 & 0.120 & - & 0.914 & 0.144 & 1.44 & $6521^{*}$ \\
\hline Gram & -2.52 & 1.65 & -0.02 & - & 0.906 & 0.152 & 1.51 & $5861^{*}$ \\
\hline Moissev & -0.76 & 0.22 & $5 \times 10^{-4}$ & $4 \times 10^{-4}$ & 0.908 & 0.149 & 1.49 & $4034^{*}$ \\
\hline
\end{tabular}

Where: $\mathrm{R}^{2} \mathrm{Aj}=$ adjusted coefficient of determination; Syx $=$ standard error of the estimate; $\mathrm{CV} \%=$ coefficient of variation in $\%$; $\mathrm{F}=$ value of $\mathrm{F}$ of the analysis of variance; $\beta 0, \beta 1, \beta 2, \beta 3=$ coefficients, ${ }^{*}$ Significant at $5 \%$ probability. 


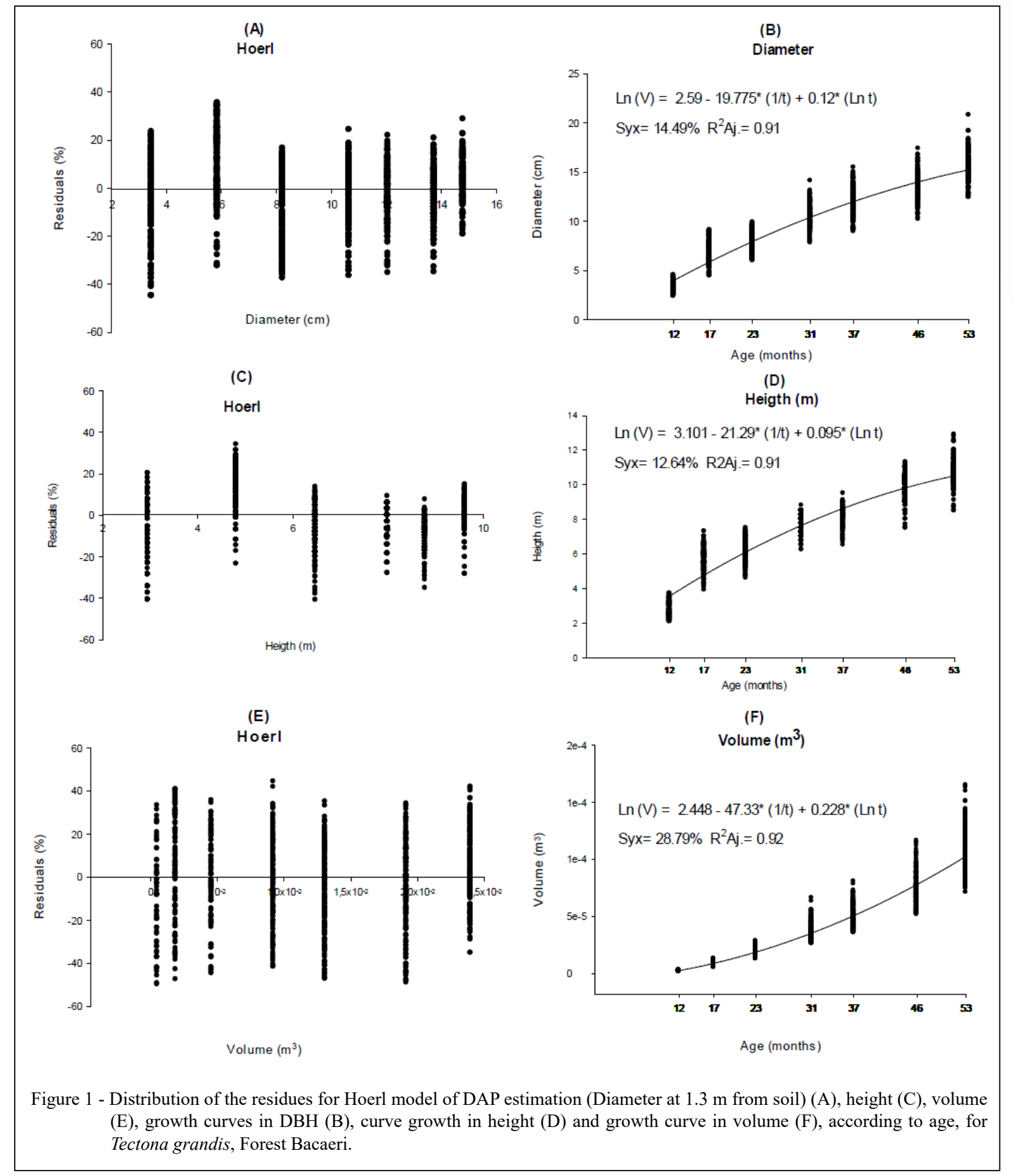

diameter and height, where the equation of the Hoerl model presented a higher adjusted coefficient of determination (0.928) and for the standard error of the estimate the lowest value (28.9), as well as homogeneous dispersion of residues (Table 6 and Figure 1E). The initial behavior growth of teak height is rapid. Considering that is a heliophite species, requiring a high demand for light, intolerant to shade, this behavior indicates good adaptation of the species to the region.

Distribution of the volume residues showed similarity with the distribution of diameter and height residues, and the Hoerl model stood out as presenting the best statistical parameter and adequate residual dispersion (Figure 1E). The pattern presented coincides with the typical pattern of tree growth, 
Table 5 - Statistical parameters of the equations tested to adjust the growth in height as a function of age of the Forest Bacaeri.

\begin{tabular}{|c|c|c|c|c|c|c|c|c|}
\hline \multirow[t]{2}{*}{ Equation } & \multicolumn{4}{|c|}{ 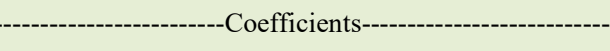 } & \multirow[b]{2}{*}{$\mathrm{R}^{2} \mathrm{Aj}$} & \multirow[b]{2}{*}{ Syx } & \multirow[b]{2}{*}{$\mathrm{CV} \%$} & \multirow[b]{2}{*}{$\mathrm{F}$} \\
\hline & $\beta_{0}$ & $\beta_{1}$ & $\beta_{2}$ & $\beta_{3}$ & & & & \\
\hline Schumacker & 2.68 & -19.05 & - & - & 0.90 & 0.126 & 1.71 & $12072.5^{*}$ \\
\hline Backman & -4.80 & 3.36 & -0.39 & - & 0.89 & 0.133 & 1.80 & $5424.4^{*}$ \\
\hline Hoerl & 3.10 & -21.29 & -0.09 & - & 0.90 & 0.126 & 1.71 & $6072.5^{*}$ \\
\hline Gram & -2.28 & 1.50 & -0.02 & - & 0.88 & 0.138 & 1.88 & $4922.7^{*}$ \\
\hline Moissev & -0.91 & 0.23 & $6 \times 10^{-3}$ & $5 \times 10^{-4}$ & 0.90 & 0.132 & 1.79 & $3676.3^{*}$ \\
\hline
\end{tabular}

Where: $\mathrm{R}^{2} \mathrm{Aj}=$ adjusted coefficient of determination; Syx = standard error of the estimate; $\mathrm{CV} \%=$ coefficient of variation in $\%$; $\mathrm{F}=$ value of $\mathrm{F}$ of the analysis of variance; $\beta 0, \beta 1, \beta 2, \beta 3=$ coefficients, ${ }^{*}$ Significant at $5 \%$ probability.

which is sigmoidal, where initially the volume growth curve presents a slow increase, but the volumetric growth curve has an exponential increase (Figure $1 \mathrm{~F})$. The clonal stands of teak in LFIS in the Forest Bacaeri showed an increase in characteristic height of the juvenile phase of the species, demonstrating rapid growth during the study period.

There was an increase in the assessed period to the variable diameter,height and volume, and their respective ICA and IMA (Table 7). Growth in DBH at 5 years of age in the city of Nossa Senhora do Livramento-MT, Brazil was $13.9 \mathrm{~cm}$ (CALDEIRA \& OLIVEIRA, 2008), a result that was lower than the $14.8 \mathrm{~cm}$ evaluated at 53 months. The mean annual increment (MAI) in diameter at 46 months of age presented a value of $3.587 \mathrm{~cm}_{\text {year }}{ }^{-1}$, a superior result presented to that obtained by Silva, Silva and Miranda (2014), who reported $2.694 \mathrm{~cm}_{\text {year }}{ }^{-1}$ in 48 months in the region of Alta Floresta-MT.

The mean annual increase in height was $2.849 \mathrm{~m} \mathrm{year}^{-1}$ at 37 months of age, followed by a constant reduction (Table 7). This result was superior to that observed by Pelissari, Caldeira and Drescher (2013), who verified a value of $2.63 \mathrm{~m} \mathrm{year}^{-1}$ at 36 months and also that of TONINI et al. (2009), who obtained a value of $2.341 \mathrm{~m}^{\text {year }}{ }^{-1}$, at 36 months of age. According to these authors, the low increase in height may have been influenced by the genetic (seminal) material used and inadequate soil management. It is still important to point out that the decrease of the average heights in the densified stands (ARAÚJO et al., 2014), as a consequence of the level of competition between individuals (BERGER et al., 2002), thus justifying superior results in forest-livestock systems.

The current annual increment (CAI) in height presented an initial increase, with a value of $1.86 \mathrm{~m}$ year $^{-1}$, and at 53 months the value was 0.467 $\mathrm{m}$ year $^{-1}$, there was a marked reduction in its CAI for height. The CAI value at 37 months was of 0.791 $\mathrm{m}_{\text {year }}{ }^{-1}$, higher than the result of MACEDO et al. (2005), who presented values of $0.611 \mathrm{~m}$ year $^{-1}$ at 36 months of age.

The mean annual increment (MAI) and current annual increment (CAI) presented volume

Table 6 - Statistical parameters of the equations tested to adjust the growth in volume as a function of age of the Forest Bacaeri.

\begin{tabular}{|c|c|c|c|c|c|c|c|c|}
\hline \multirow[t]{2}{*}{ Equation } & \multicolumn{8}{|c|}{ 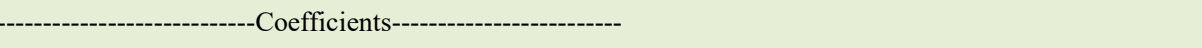 } \\
\hline & $\beta_{0}$ & $\beta_{1}$ & $\beta_{2}$ & $\beta_{3}$ & $\mathrm{R}^{2} \mathrm{Aj}$ & Syx & $\mathrm{CV} \%$ & $\mathrm{~F}$ \\
\hline Schumacker & -1.46 & -52.8 & - & - & 0.92 & 0.297 & 59.32 & 12446.1 \\
\hline Backman & -19.88 & 7.8 & -0.87 & - & 0.91 & 0.299 & 61.06 & $5792.2^{*}$ \\
\hline Hoerl & -2.44 & -47.3 & 0,22 & - & 0.92 & 0.287 & 57.11 & $6256.6^{*}$ \\
\hline Gram & -14.23 & 3.7 & -0.05 & & 0.91 & 0.308 & 63.05 & $5400.3^{*}$ \\
\hline Moissev & -10.57 & 0.5 & -0.013 & $1 \times 10^{-4}$ & 0.91 & 0.296 & 60.74 & $3941.1^{*}$ \\
\hline
\end{tabular}

Where: $\mathrm{R}^{2} \mathrm{Aj}=$ adjusted coefficient of determination; Syx = standard error of the estimate; $\mathrm{CV} \%=$ coefficient of variation in $\%$; $\mathrm{F}=$ value of $\mathrm{F}$ of the analysis of variance; $\beta 0, \beta 1, \beta 2, \beta 3=$ coefficients, ${ }^{*}$ Significant at $5 \%$ probability. 
Table 7 - Growth diameter (DBH), height $(\mathrm{H})$ and volume of Tectona grandis, Forest Bacaeri.

\begin{tabular}{|c|c|c|c|c|c|c|c|c|c|}
\hline Age & $\mathrm{DBH}$ & MAI & CAI & $\mathrm{H}$ & MAI & CAI & $\mathrm{V}$ & MAI & CAI \\
\hline months & \multicolumn{3}{|c|}{ 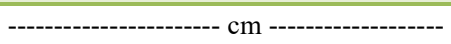 } & \multicolumn{3}{|c|}{ 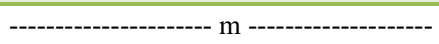 } & \multicolumn{3}{|c|}{ 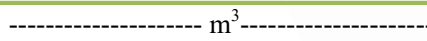 } \\
\hline 12 & 3.461 & 3.461 & - & 2.956 & 2.956 & - & 0.002 & 0.002 & - \\
\hline 17 & 5.869 & 4.136 & 2.398 & 4.816 & 3.399 & 1.860 & 0.008 & 0.006 & 0.006 \\
\hline 23 & 8.230 & 4.294 & 2.371 & 6.483 & 3.383 & 1.670 & 0.014 & 0.008 & 0.006 \\
\hline 31 & 10.650 & 4.123 & 2.419 & 7.997 & 3.095 & 1.513 & 0.027 & 0.011 & 0.013 \\
\hline 37 & 12.064 & 3.913 & 1.414 & 8.786 & 2.849 & 0.791 & 0.037 & 0.012 & 0.011 \\
\hline 46 & 13.749 & 3.587 & 1.685 & 9.627 & 2.511 & 0.841 & 0.048 & 0.013 & 0.010 \\
\hline 53 & 14.803 & 3.352 & 1.053 & 10.09 & 2.285 & 0.467 & 0.107 & 0.024 & 0.059 \\
\hline
\end{tabular}

values of $0.006 \mathrm{~m}^{3}$ year $^{-1}$ at 17 months, followed by a progressive increase up to 53 months of age. In Monte Dourado, PA, Brazil, and MAI of $0.008 \mathrm{~m}^{3}$ year ${ }^{-1}$ was obtained at 36 months of age (ROSSI et al., 2011), and a study by MACEDO el al. (2005), the mean volume at 36 months was $0.0012 \mathrm{~m}^{3}$ year ${ }^{-1}$ (Table 7). In the city of Nossa Senhora do Livramento-MT, Brazil, Pelissari, Caldeira and Drescher (2013) obtained an MAI at 36 months of $0.0103 \mathrm{~m}^{3}$ year ${ }^{-1}$, and the MAI value at 37 months in the present study was $0.012 \mathrm{~m}^{3}$ year $^{-1}$, a higher value of the mean annual increase for volume growth, indicating good development of the plants in the place of study.

Parameters of growth, height and volume were superior in relation to scientific studies of dendomentric survey with specie, it is justified by use of clonal seedlings of teak and the spatial arrangement that contributed to the reduction of competition between plants and also as edaphoclimatic conditions of the place that favor the development of plants.

\section{CONCLUSION}

The model of Hoerl was which presented better residual distribution and better adjustment of growth in diameter, height and volume to teak in forest-livestock integrated production system. The observed results of MAI and CAI of diameter, height and volume were superior in relation to other scientific studies with teak, indicating their viability in integrated systems with pastures in the region.

\section{DECLARATION OF CONFLICT OF INTERESTS}

The authors declare no conflict of interest. The founding sponsors had no role in the design of the study; in the collection, analyses, or interpretation of data; in the writing of the manuscript, and in the decision to publish the results.

\section{AUTHORS' CONTRIBUTIONS}

All authors contributed equally for the conception and writing of the manuscript. All authors critically revised the manuscript and approved of the final version.

\section{REFERENCES}

ARAÚJO, J.G., et al. Growth in diameter and heightof natural regeneration of Eremanthus incanus. Floresta, 44(2):217-228, 2014. Available from: $<$ http://dx.doi.org/10.5380/rf.v44i2.31362>. Accessed: Dec. 20, 2017. doi: 10.5380/rf.v44i2.31362.

ALVARES, C.A.; et al. Köppen's climate classification map for Brazil. Meteorologische, 22(6):711-728, 2013. Available from: $<$ http://dx.doi.org/10.1127/0941-2948/2013/0507>. Accessed: Jan. 23, 2018. doi: 10.1127/0941-2948/2013/0507.

BERGER, R.; et al. Growth rate of Eucalyptus saligna Smith clone affected by spacing and fertilization. Ciência Florestal, 12(75):87, 2002. Available from: $<$ http://dx.doi.org/10.5902/198050981682>. Accessed: Jan. 12, 2018. doi: 0.5902/198050981682.

CALDEIRA, S.F., OLIVEIRA, D.L.C. Selective thinning in Tectona grandis plantations with different ages. Acta Amazônica, 38(3):223-228, 2008. Available from: <http://dx.doi.org/10.1590/ S0044-59672008000200005>. Accessed: Feb. 01, 2018. doi: 10.1590/S0044-59672008000200005.

DRESCHER, R. et al. Selective thinning in Tectona grandis plantations with different ages. Advances in Forestry Science, 1(2):65-70, 2014. Available from: <http://dx.doi.org/10.1590/ S0044-59672008000200005>. Accessed: Jan. 10, 2018. doi: 10.1590/S0044-59672008000200005.

EMBRAPA - Empresa Brasileira de Pesquisa agropecuária. Sistema brasileiro de classificação de solos. Brasília, 3.ed., Embrapa, 2013. 353p.

FAMATO - Federação da Agricultura e Pecuária do Estado de Mato grosso. Diagnóstico de Florestas Plantadas do Estado de Mato Grosso. Cuiabá, IMEA, 2013, 121p.

MACEDO, R.L.G. et al. Desenvolvimento inicial de Tectonagrandis L.f. (teca) em diferentes espaçamentos no município de Paracatu, MG. Revista Cerne, 11 (2):61-69, 2005. Available from: <http://www. redalyc.org/articulo.oa?id=74411107> . Accessed: Jan. 25, 2018. 
MEDEIROS, R. A. et al. Silvicultural and economic analysis of clonal and seminal plantations of Tectona grandis L.F. in Taungya System.. Revista Árvore, 39(5)893-903, 2015. Available from: $<$ http://dx.doi.org/10.1590/0100-67622015000500012>. Accessed: Feb. 02, 2018. doi: 10.1590/0100-67622015000500012.

MORETTI, M. S. et al. Growth of plants of teak in monoculture and Taungya system with corn, Figueirópolis D'Oeste, Mato Grosso. Scientia Forestalis, 42(2):269-277, 2014. Available from: $<$ https://www.ipef.br/publicacoes/scientia/nr102/ cap11.pdf $>$. Accessed: Dec. 27, 2017

NIERI, E. M.etal. Silvicultural behavior of forest species in arrangement for a livestock-forestry integration. Floresta, 48(2):195-202, 2018. Available from: <http://dx.doi.org/10.5380/rf.v48i2.54744> Accessed: Aug. 29, 2018. doi: 0.5380/rf.v48i2.54744.

NIERI, E.M. et al. Silvicultural performance of forest species introduced in integrated livestock forest system in Lavras, MG, Brazil. Ciência Rural, 47(12):1-8, 2017. Available from: <http:// dx.doi.org/10.1590/0103-8478cr20161106>. Accessed: Jan. 29, 2018. doi: 10.1590/0103-8478cr20161106.

PAULA, R. R. et al. Eucalypt growth in monoculture and silvopastoral systems with varied tree initial densities and spatial arrangements. Agroforestry Systems, 87(6):1295-1307, 2013 Available from: <http://dx.doi.org/10.1007/s10457-013-9638-5>. Accessed: Dec. 29, 2016. doi: 10.1007/s10457-013-9638-5.

PELISSARI, A.L.; et al. Quantitative and qualitative development of Tectona Grandis L.f. in Mato Grosso. Revista Floresta e Ambiente, 3(1):40-45, 2013. Available from: <http://dx.doi. org/10.4322/floram.2013.027>. Accessed: Nov. 23, 2017. doi:10.4322/floram.2013.027.
ROSSI, A. S. et al. Relação hipsométrica e crescimento de Tectona grandis L. f. no município de Monte Dourado, PA. Scientia Forestalis, 39(4):301-307, 2011. Available from: $<$ https://www.ipef.br/publicacoes/scientia/nr91/cap02.pdf $>$. Accessed: Nov. 23, 2017.

SCHUHLI, G.S., PALUDZYSZYN FILHO, E. O cenário da silvicultura de teca e perspectivas para o melhoramento genético. Pesquisa Florestal Brasileira, 30(1):217-230, 2010. Available from: <http://dx.doi.org/10.4336/2010.pfb.30.63.217>. Accessed: Sep. 30, 2017. doi: 10.4336/2010.pfb.30.63.217.

SILVA, A. M. C.et al. Occupational accidents related tocattleslaughter in Mato Grosso, Brazil. Cadernos Saúde Coletivo, 24(1):9-13, 2016. Available from: <http://dx.doi. org/10.1590/1414-462X201500040138>. Accessed: Dec. 12, 2017. doi: 10.1590/1414-462X201500040138.

SILVA, F. R.; et al. Growth of Tectona grandis at a plantation located in Alta Floresta, Mato Grosso. Floresta, 44(4):577-588, 2014. Available from: <http://dx.doi.org/10.5380/rf.v44i4.29699>. Accessed: Jan. 23, 2018. doi: 10.5380/rf.v44i4.29699.

SINHA, S. K et al. Dendroclimatic analysis of teak (Tecnonagrandis L.F.) annual rings from two locations of peninsular India. Current science, 5 (3):84-88, 2011. Available from: <https://core.ac.uk/download/pdf/151494532. pdf $>$. Accessed: Jan. 21, 2018.

TONINI, H.; et al. Crescimento da teca (Tectonagrandis) em reflorestamento na Amazônia Setentrional. Pesquisa Florestal Brasileira, 3 (2):05-14, 2009. Available from: <http//dx.doi. org/:10.4336/2009.pfb59.05>. Accessed: Sep. 30, 2016. doi: 10.4336/2009.pfb.59.05. 